\title{
ALTERNATÍV ISKOLA, ALTERNATÍV ÉTKEZÉS - VEGETÁRIÁNUS ÉS VEGÁN ÉTELSOROK TÁPANYAG VIZSGÁLATA PEST MEGYÉBEN
}

\section{ALTERNATIVE SCHOOL, ALTERNATIVE DIET - SURVEY ON NUTRIENT CONTENT OF VEGETARIAN AND VEGAN MENUS IN PEST COUNTY}

BÉNYI MÁRIA1', MAJZIK BENCÉNÉ2

'BFKH Népegészségügyi Főosztály

2PMKH Érdi Járási Hivatala Népegészségügyi Osztály

DOI: https://doi.org/10.29179/EgTud.2019.3-4.32-40

\begin{abstract}
Összefoglalás
A közétkezetésre vonatkozó jogszabály 2014 óta hatályos. Az alternatív nevelési oktatási intézményekben elöször 2018-ban végeztünk vizsgálatokat azzal kapcsolatban, hogy az ott szolgáltatott étkezés mennyiben felel meg a jogszabályi - a gyermekek élettani szükségleteit tartalmazó - elöírásoknak. Egy vegetáriánus és vegán étrend étlapja és 2 hetes anyagkiszabata alapján végzett vizsgálatok eredményeit mutatjuk be. A tapasztalat alapján mindkettő alultervezett volt energiatartalmát tekintve, 30-40\%-os hiány mutatkozott fehérjéből és szénhidrátból, a zsír abszolút értéke megfelelő volt. Kevés volt a kalcium, vas, cink magnézium, a $B_{1}, B_{2}, B_{12}$ vitamin, a vegán étrendben az A-vitamin is. Kedvezőnek mondható - a sok zöldség és gyümölcs miatt - a rosttartalom, és a $\mathrm{C}, \mathrm{B}_{6}, \mathrm{E}$ - vitamin mennyiség, valamint a só tartalom a kívánatos határon belül maradt. A felmérés az ebédek vizsgálatára terjedt ki, melyek arányosan az egész napra eső tápanyag 35\%-ára vonatkozó előírásokat nem elégítették ki, bár a vegetáriánus étrendbe beilleszthető élelmiszerek teljes értékü ételek készítését teszik lehetővé.
\end{abstract}

Kulcsszavak: vegetariánus, vegán, diéta, közétkeztetés, alultápláltság

$\begin{array}{ll}\text { EGÉSZSÉGTUDOMÁNY } & \mathbf{2 0 1 9 ; 6 3 ( 3 - 4 ) : ~ 3 2 - 4 0 .} \\ \text { HEALTH SCIENCE } & \\ \text { Közlésre érkezett: } & \text { 2019. november } 2 . \\ \text { Submitted: } & \text { 2 November } 2019 \\ \text { Elfogadva: } & \text { 2019. december } 2 . \\ \text { Accepted: } & \text { 2 December } 2019\end{array}$

Levelezési cím/Correspondence: DR. BÉNYI MÁRIA

1089 Budapest, Delej u. 51. XX. lh. fsz. 5. benyi.maria@gmail.com 


\section{Summary}

The law on public catering has been in force since 2014. In 2018, for the first time, we conducted a research in alternative education institutions with the question to what extent the meals - served in the school - meet the legal requirements regarding the physiological needs of children. We present the results of a survey based on measuring a 2-week vegetarian and vegan menu focusing on its nutritional value. The results showed that both types of diets were underplanned in terms of their energy content, with protein and carbohydrate deficiencies of $30-40 \%$ and only the absolute fat content was sufficient. The amount of calcium, iron, zinc magnesium, vitamins $B_{1}, B_{2}, B_{12}$, and vitamin $A$ was low in the vegan diet. Due to the high content of vegetables and fruits the fiber content and vitamin $\mathrm{C}, \mathrm{B}_{6}$, vitamin $\mathrm{E}$, as well as salt content remained within the desirable limits. The survey included a study of lunches, which, proportionally, did not meet the requirements of $35 \%$ of the nutrient daily intake, although foods that can be incorporated into a vegetarian diet make possible to prepare a nutritionally complete meal.

Keywords: vegetarian, vegan, diet, public catering, malnutrition

\section{Bevezetés}

2014 óta Magyarországon a közétkeztetésre vonatkozó táplálkozás-egészségügyi előírásokról szóló jogszabályt (a továbbiakban: Rendelet) kell figyelembe venni azoknak a szolgáltatóknak is, amelyek gyermekeket - 0-18 éves korig - étkeztetnek [1]. A Rendelet, melyet az akkori Országos Élelmezés- és Táplálkozástudományi Intézet szakemberei dolgoztak ki, az élettani igényeket figyelembe véve, megszabja az adandó és adható élelmiszereket. Meghatározza azok korcsoportonkénti, heti és/vagy napi adagját. A Rendelet betartását a népegészségügyi hatóság ellenőrzi. A Rendelet bevezetése óta eltelt 4 év tapasztalatai alapján a közép-magyarországi régió iskoláiban végzett ellenőrzések számítások és laboratóriumi vizsgálatok - alapján elmondható, hogy a szolgáltatott étrendekben az előírtnál magasabb a só- és zsírtartalom, kevesebb a tej, egyes helyeken a zöldség-gyümölcs és teljes kiőrlésű gabonából készült élelmiszer. Müködnek hazánkban ún. alternatív nevelési-oktatási intézmények is, melyekben a többségtől eltérő tanrendet és étkeztetést biztosítanak a gyermekek részére. Ezzel a vizsgálattal az volt a célunk, hogy képet alkossunk arról, hogy egy átlagostól eltérő tanintézményben felszolgált ételsor milyen mértékben felel meg a gyermekek életkori igényeinek, a Rendelet elöírásainak. 


\section{Adatok, módszer}

A vizsgálatba egy Pest megyei iskolát vontunk be, mely Waldorf módszerrel müködik. A vizsgált időszak: 2018. február 19. - 2018. március 2.

Az étlapokat és anyagkiszabatokat az illetékes járási hivatal munkatársa kérte be a szolgáltatótól 10 napra vonatkozóan. Az iskolában két étrend is készült: egy vegetáriánus és egy vegán. Az iskola csak ebédet biztosított, így a számítások során az egész napos elvárás 35\%-ával vetettük össze a kapott értékeket a 11-14 éves korcsoportra vonatkozóan.

Az ételek változatosságát a benyújtott étlapok alapján értékeltük. Az adatok a NUTRICOMP 4.0 számítógépes programba kerültek rögzítésre és az értékelés is ezzel a programmal készült. A vizsgált paraméterek a következők voltak: energiatartalom, föbb tápanyag összetevők (fehérje, zsír, szénhidrát), rosttartalom, só, fontosabb makro- és mikroelemek (nátrium, kalcium, vas, cink, magnézium), vitaminok (A (retinol-ekivalens), $\mathrm{D}, \mathrm{C}$ és $\left.\mathrm{B}_{1}, \mathrm{~B}_{2}, \mathrm{~B}_{6}, \mathrm{~B}_{12}\right)$.

\section{Eredmények}

\section{Vegetáriánus és vegán ebéd}

Az étlapok formai szempontból megfelelőek voltak: energia- és tápanyagtartalom, só és allergének feltüntetésre kerültek.

A Rendelet alapján elvárt értékeket, az általunk kiemelt paraméterek szempontjából, az 1. táblázat „ajánlás” oszlopában tüntettük fel. A további oszlopokban találhatók a szolgáltató által megadott adatok alapján kapott számítási eredmények a vegetáriánus és vegán étrendủ ebédben. 
1. táblázat A 11-14 éves korcsoport táplálkozás-élettani igényei és a vegetáriánus- illetve vegán étrendben számított tápanyag-, mikroelem- és vitamin tartalom

Table 1 Nutritional requirements of schoolchildren aged 11-to-14-years and the calculated nutrient, micronutrient and vitamin content of the vegan and vegetarian menu

\begin{tabular}{lcccc}
\hline & Mértékegység/ & $\begin{array}{c}\text { Ajánlás } \\
\text { recommended } \\
\text { (az egész napi } \\
\text { Peasurement } \\
\text { unit }\end{array}$ & $\begin{array}{c}\text { Vegetáriánus ebéd } \\
\text { számított értékek } \\
\text { (10 nap átlaga) } \\
\text { vegetarian menu } \\
\text { calculated values } \\
\text { (10-day mean) }\end{array}$ & $\begin{array}{c}\text { Vegán ebéd } \\
\text { számított értékek } \\
\text { (10 nap átlaga) } \\
\text { vegan menu }\end{array}$ \\
(10-day mean)
\end{tabular}

Az 1. táblázatban látható, hogy a korcsoport számára ajánlott energiaigényt 10 nap átlagában egyik étrend sem elégítette ki. Érdemi eltérés a két ebéd energiatartalma között nem volt. Az 1. ábrán napi bontásban kerül bemutatásra az ebédek energiatartalma. Ebből kitűnik, hogy a 3. és a 4. napon érte el, illetve közelítette meg az energiatartalom az életkor számára előírt alsó határt. 


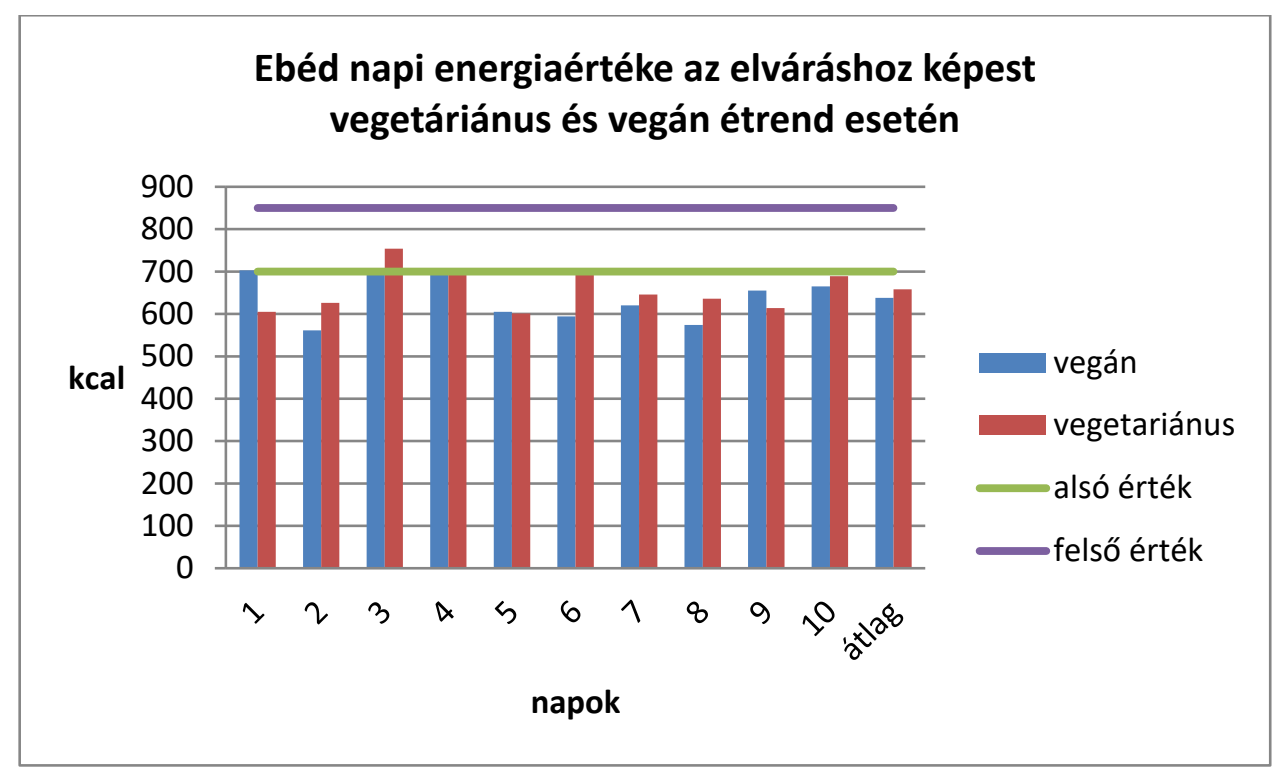

1. ábra A 11-14 évesek számára készült vegetáriánus és vegán ebéd energiatartalma az elvárt értékek minimum és maximum értékéhez képest, napi bontásban 10 egymást követő munkanap

Figure 1 Energy value of vegetarian and vegan lunch prepared for schoolchildren aged 11-to-14-years, compared to minimum and maximum value of the required values, on a daily basis for the period of 10 consecutive days

A tápanyagok közül a fehérje mennyisége a vegetáriánus étrendben 68\%-a, a vegánban $62 \%$-a volt a minimálisan javasoltnak. A szénhidrát a vegetáriánus ebédben 69\%-a, a vegánban 79\%-a volt az elvártnak. A zsírtartalom a vegetáriánus ételben megfelelö, a vegánban 82\%-a volt az előírásnak. Azzal, hogy fehérje és szénhidrát abszolút értékben kevés, a zsír energia százaléka a megengedett 30\% helyett a vegetáriánus étrendben $40 \%$, a vegánban $32 \%$ volt.

Az összes kalcium mennyisége az elvárt értéknek 56\%-a volt a vegetáriánus és 40\%-a a vegán étrendekben, 10 nap átlagában. (A tej alapú kalciumot csak jelzésként adjuk meg az 1. táblázatban, tekintettel arra, hogy a tej-tejtermék jellemzően nem az ebéd része, hanem a kisétkezéseké. Látható, hogy a vegetáriánus étrendnél $82 \%$-a teljesült az elvárt mennyiségnek, a vegán étrendben viszont közel nulla értéket kaptunk a tej alapú kalciumra.)

A só értékek mindkét étrendben az elöírt határon (2-4 g) belül maradtak. A nátrium mennyisége mintegy 40\%-kal magasabb a javasolt értéknél. 
Vas, cink és magnézium tekintetében mindkét étrend kevesebbet tartalmazott az elvártnál. Az összes vas a vegetáriánus étrendben 28\%-kal, a vegánban 23\%-kal kevesebb volt az előírtnál. (Ez utóbbiban állati eredetű vas nem fordult elő.) A cink mennyisége a vegetáriánusban 37\%, a vegánban 47\%-os negatív irányú eltérést mutatott. A magnézium mintegy $15 \%$-kal volt alatta a kívánatos értéknek.

$A$ vízben oldódó vitaminok közül a $C$ és $B_{6}$ mennyisége elegendő, a $B_{1}, B_{2}, B_{12}$ kevés. Tekintettel arra, hogy állati eredetű termék nem szerepelt a vegán étrendben, a B12 vitamin tartalma gyakorlatilag nulla.

A zsírban oldódó vitaminok közül kedvező volt az étrendek E-vitamin tartalma. Az A-vitamin - melyet retinolekvivalensben adtuk meg - a vegetáriánus étrendben megfelelö, a vegánban kevés volt. A D-vitamin minimális mennyiségben volt jelen mindkét étrendben. Értékét csak jelzésként adtuk meg - hiszen a vegyes étrendből sem lehet táplálékkal elegendő D-vitamint bevinni a szervezetbe. Kedvezőnek mondható, hogy mindkét étrendben a hozzáadott cukor energiaszázaléka alatta maradt a 10\%-nak. Az ételek rosttartalma az elvárt 120\%-a volt.

\section{Megbeszélés}

A vizsgált iskolai étkeztetés jelentős eltérést mutatott a Rendelethez képest. Az előírástól eltérően - mely szerint az iskolában napi háromszori étkezést kell biztosítani -, csak egy étkezésről, az ebédről rendelkeztek dokumentációval.

A kapott eredmények a vegetarianizmussal kapcsolatos tankönyvi adatokat jórészt visszaigazolják [2]. Az ebédek energiatartalma szinte minden nap alacsonyabb, mint amit a Rendelet elvár. (Ez az átlagos iskolákban gyakorlatilag nem fordul elö, tapasztalataink szerint.) Tekintettel arra, hogy az étlapokon az energiatartalmat feltüntették, azzal a szolgáltató és a fogyasztók (szülők!) is tisztában lehettek. Felmerül az alultáplálás lehetősége. (A feltételes módot az is indokolja, hogy csak az ebédet vizsgáltuk, így az egész napos energiamennyiségről nem áll rendelkezésre adat. Nem ismerjük továbbá a gyermekek tömegét sem, így az energia igényről sem alkothatunk pontos képet.)

A tápanyag-összetevők közül az elöírtnál 30-40\%-kal alacsonyabb a fehérje és a szénhidrát mennyisége is. A teljes értékü fehérje a fejlődésben, növekedésben lévő szervezet számára elengedhetetlen. Az ilyen nagymértékü hiány nehezen pótolható. A fehérjehiányos állapot elöidézésének veszélye fennáll. Külön említést érdemel a kalcium, 
amelynek alacsony értéke a fejlődés időszakában kritikus. Tej- és tejtermékek nélkül a megfelelö kalcium-szint hozzátáplálással érhető el. Ez lehet tabletta, vagy kalciummal dúsított növényi eredetű tej is. Az ásványi anyagok közül a vashiány nemcsak mennyiségi szempontból jelent problémát, hanem azért is, mert a növényi eredetü vas csak 3-8\%-ban, míg az állati fehérjéből származó, hem-kötésü vas 15-20\%-ban szívódik fel [3]. Jelen esetben pozitívum, hogy kellö mennyiségü C-vitamin van az ételekben, ami növeli a növényekben található vas felszívódást.

A „B” vitaminokból mindkét étrend hiányos a B6 kivételével. Az idegrendszer fejlődése, működése és a megfelelő vérképzés érdekében az étrend kiegészítésre szorul. $\mathrm{Az}$ „A” vitamin csak a vegán étrendben kevés. Tekintettel arra, hogy számos növény tartalmaz A vitamin előanyagot (alfa-, béta, gamma-karotin, béta-kriptoxantin), nagyobb odafigyeléssel ez a probléma kiküszöbölhető. Figyelembe kell venni, hogy a karotinoidok felszívódása csak 20-50\%, és ha kevés a zsír az ételben, a hasznosulás még rosszabb [4].

A vegetáriánus és vegán étrendet fogyasztók száma az utóbbi időben világszerte erőteljesen növekszik. A szakmai megítélés ezekkel az alternatív étrendekkel kapcsolatban nemzetközi szinten sem egységes. Különösen a gyermekkori növényi alapú étkezés körül élesek a viták [5]. Hazánkban a hivatalos táplálkozás-egészségügyi szakmai állásfoglalás az, hogy a vegán étrenddel semmiképp, vegetáriánussal is csak nagy odafigyeléssel lehet kielégíteni egy fejlődésben lévő gyermek élettani igényét. Mint az Országgyűlés közétkeztetésről szóló 2016/46 infojegyzetében [6] is olvasható:

„Az alternatív (vegetáriánus) étrendek közül a közétkeztetésben csak a szakszerüen, dietetikus által összeállitott és felügyelt szemi-vegetáriánus illetve lakto-ovo-vegetáriánus étrend fogadható el. A szigorú vegetáriánus étrend bizonyos tápanyagok vonatkozásában (Ca, Fe, Zn, D-vitamin, B6-, B12-vitamin) nem fedezi a szükségletet.” A Pécsi Tudományegyetem Egészségtudományi Karának munkatársai egy 2016-ban publikált írásukban [7], kritikusan értékelik a növény alapú étrendekkel kapcsolatos hazai álláspontot, és kiemelik a növény alapú étrendek elhízásra, szív-és érrendszeri és a daganatos megbetegedésekre vonatkozó jótékony hatásait. Az elhízással kapcsolatban egy metaanalízisre alapuló tanulmányból bemutatják, hogy a vegetáriánus nők 2,9-10,6 kg-mal, a férfiak 4,6-12,6 kg-mal könnyebbek a vegyes táplálkozásúakhoz képest. Felhívják a szerzők a figyelmet arra is, hogy az IARC 2015-ben a vörös húsokat a 2/a (valószínüleg rákkeltő), a feldolgozott húskészítményeket 1/a (emberre rákkeltő) besorolásba tették. A probléma tehát összetett - és semmiképpen nem írható le egy jogszabállyal. 
Amiket minden körülmények között figyelembe kell venni, tekintettel arra, hogy alapjogok:

"Minden gyermeknek joga van a megfelelö testi, szellemi és erkölcsi fejlödéséhez szükséges védelemhez és gondoskodáshoz." "A szülőknek joguk van megválasztani a gyermeküknek adandó nevelést." [8]

Ezen túl a gyermeknek joga, hogy: „a nevelési és a nevelési-oktatási intézményben biztonságban és egészséges környezetben neveljék és oktassák, óvodai életrendjét, iskolai tanulmányi rendjét pihenőidő, szabadidő, testmozgás beépítésével, sportolási, étkezési lehetőség biztosításával életkorának és fejlettségének megfelelően alakítsák ki”.

Tehát: a szülőnek joga van megválasztani a gyermeke oktatásának, nevelésének helyét és módját. Joga van tudni azt is, hogy gyermeke élettani sajátságainak megfelelő ellátást kap-e az adott intézményben az élelmezés során. Ennek ismeretében kötelessége a szülőnek a családban a gyermeket a további, a fejlődéséhez elengedhetetlen táplálékkal, ha szükséges, étrend-kiegészítőkkel ellátni.

Saját felmérésünk alapján elmondható, hogy a vegetáriánus és a vegán ebéd a napi adandó tápérték arányában alacsony volt, és több mikroelem és vitamin tekintetében sem elégítette ki az életkori igényeket. Amennyiben a szülök napi szinten, a további étkezések során nem pótolják a hiányosságokat, alultápláltság (mennyiségi és minőségi éhezés) léphet fel. A népegészségügyi szakembereknek tehát érdemes ezeket az étrendeket vizsgálni, hogy a szolgáltatóknak és szülőknek kellő tájékoztatást adhassanak a gyermekek megfelelő fejlődése érdekében.

\section{Nyilatkozat:}

A cikk végleges változatát a társszerző is elolvasta a közleményt beadás előtt, valamint hozzájárult a megjelenéshez.

Érdekeltségek:

A szerzőknek nincsenek a tartalmat érintő érdekeltségeik.

Anyagi támogatás:

A cikkhez szükséges vizsgálat anyagi támogatásban nem részesült.

A szerzök részvétele a közlemény létrehozásban:

M.B-né: adatok bekérése, B.M.: ötlet, adatbevitel, értékelés, irodalmazás, közlemény megírása 


\section{Irodalom:}

1. 37/2014. (IV. 30.) EMMI rendelet a közétkeztetésre vonatkozó táplálkozás-egészségügyi elöírásokról

2. Antal Magda: Különleges táplálkozási formák in: Táplálkozás Diéta. Szerk.: Barna Mária, Medicina Könyvkiadó, Budapest, 1996. pp. 145-147

3. Rodler Imre: Energia és tápanyagforgalom In: Élelmezés- és táplálkozás-egészségtan. Szerk.: Rodler Imre. Medicina Könyvkiadó, Budapest, 2008. p. 100

4. Tápanyagtáblázat. Szerk.: Rodler Imre, Medicina, Budapest, 2008. p. 51.

5. Vega és vegán gyerekek: egészséges vagy rizikós? Pharmaonline. 2018. 04.27. http://pharmaonline.hu/cikk/vega_es_vegan_gyerekek_egeszseges_vagy rizikos Letöltve: 2019.11.02.

6. Közétkeztetés. Infojegyzet. Országgyülés Hivatala. 2016/46. 2016. szeptember 29. https://www.parlament.hu/documents/10181/595001/Infojegyzet_2016_46_kozetkeztetes.pdf/6006f29e8eab-4aa5-8f2f-60ed8275df8e Letöltve: 2019.11.03.

7. Szabó Z., Erdélyi Attila, Gubicskóné Kisbenedek Andrea és mts: A növényi alapú étrendről. Orvosi Hetilap, 2016. 157.(47) 1859-1865. https://doi.org/10.1556/650.2016.30594

8. Magyarország Alaptörvénye (2011. április 25.) XVI. cikk (1), (2)

9. A nemzeti köznevelésről szóló 2011. évi CXC. törvény (Nkt.) 46. § (3) b) 